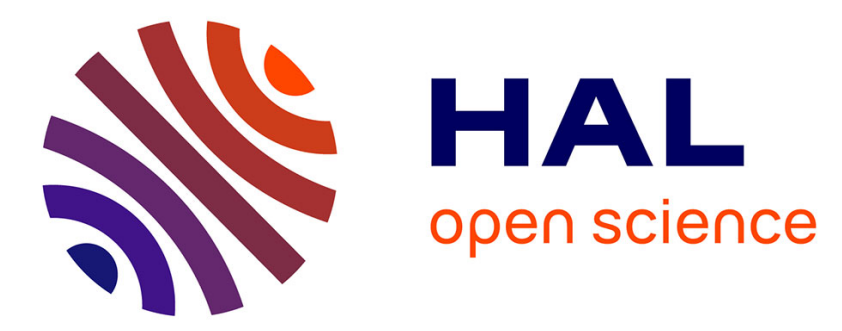

\title{
BSA and lysozyme adsorption on homoionic montmorillonite: Influence of the interlayer cation
}

Mathilde Lepoitevin, Maguy Jaber, Régis Guégan, Jean-Marc Janot, Philippe Dejardin, Francois Henn, Sébastien Balme

\section{- To cite this version:}

Mathilde Lepoitevin, Maguy Jaber, Régis Guégan, Jean-Marc Janot, Philippe Dejardin, et al.. BSA and lysozyme adsorption on homoionic montmorillonite: Influence of the interlayer cation. Applied Clay Science, 2014, 95, pp.396-402. 10.1016/j.clay.2014.05.003 . insu-01017005

\section{HAL Id: insu-01017005}

https://hal-insu.archives-ouvertes.fr/insu-01017005

Submitted on 1 Jul 2014

HAL is a multi-disciplinary open access archive for the deposit and dissemination of scientific research documents, whether they are published or not. The documents may come from teaching and research institutions in France or abroad, or from public or private research centers.
L'archive ouverte pluridisciplinaire HAL, est destinée au dépôt et à la diffusion de documents scientifiques de niveau recherche, publiés ou non, émanant des établissements d'enseignement et de recherche français ou étrangers, des laboratoires publics ou privés. 
BSA and Lysozyme adsorption on homoionic montmorillonite: influence of the interlayer cation

Mathilde Lepoitevin ${ }^{1}$, Maguy Jaber ${ }^{2}$, Régis Guégan ${ }^{3}$, Jean-Marc Janot ${ }^{1}$, Philippe Dejardin ${ }^{1}$, François Henn ${ }^{4}$, Sébastien Balme* ${ }^{1}$

${ }^{1}$ Institut Européen des Membranes, UMR5635 CNRS, Université Montpellier 2, Place Eugene Bataillon, 34095 Montpellier cedex 5, France.

${ }^{2}$ Laboratoire de Réactivité de Surface, UMR 7197 CNRS, UPMC Université Paris 06, Casier 178, 3, R. Galilée, F-94200 Ivry-sur-Seine, France.

${ }^{3}$ Institut des Sciences de la Terre d'Orléans, UMR 7327 CNRS, Université d'Orléans, 1A Rue de la Férolerie, 45071 Orléans Cedex 2, France

${ }^{4}$ Laboratoire Charles Coulomb UMR 5221 CNRS, Université Montpellier 2, Place Eugene Bataillon, 34095 Montpellier cedex 5, France.

* Corresponding author: sebastien.balme@iemm.univ-montp2.fr, Tel : 3367149118 


\begin{abstract}
The adsorption of model proteins (lysozyme and bovin serum albumin) on homoionic montmorillonite was investigated. The nature of the interlayer cation seems to be a key parameter; therefore the influence of alkali metal series $\left(\mathrm{Li}^{+}, \mathrm{Na}^{+}, \mathrm{K}^{+}, \mathrm{Rb}^{+}, \mathrm{Cs}^{+}\right)$and alkali earth metal $\left(\mathrm{Mg}^{2+}, \mathrm{Ca}^{2+}, \mathrm{Ba}^{2+}\right)$ was investigated. The localization of both proteins and their conformational modifications in the interlayer space of the natural clay mineral were studied by X-ray diffraction, transmission electronic microscopy and fluorescence experiments. Based on Langmuir model isotherms, a strong influence of interlayer cation on maximum adsorbed amount and adsorption equilibrium constant has been observed. However the usual kosmotrope/ chaotrope classification cannot be used to describe proteins adsorption.
\end{abstract}

Keywords : Protein adsorption, montmorillonite, Langmuir isotherm, homoionic-clay

\title{
Abbreviation
}

LYS : Lysozyme

BSA : Bovine Serum Albumin

Mt : Montmorillonite

IC : interlayer cation 


\section{Introduction}

The proteins adsorption on aluminosilicates is of the utmost importance (Quiquampoix, 2000). Several studies related to protein adsorption on clay minerals such as montmorillonite (Lvov Yu and Sukhorukov, 1997), kaolinite (Castellini et al., 2009) and septiolite (Alkan et al., 2006) have been reported. In general, it is well-admitted that proteins can be adsorbed on the external surface of clay mineral particles as well as intercalated in their interlamellar space (Lin et al., 2007a). However, the molecular mechanism of these adsorption phenomena remains poorly understood. Therefore, the kinetics of protein adsorption on aluminosiliceous substrates is relevant for several «hot» topics in nanotechnology: biocompatibility (since bioglasses are essentially silicates), biosensors (Si-based platforms are superficially oxidized to $\mathrm{SiO}_{2}$ in operating conditions), enzyme immobilisation (Ge et al., 2009) and finally soil chemistry.

Proteins are often classified into two groups: hard proteins which have a high internal stability such as lysozyme (LYS), and soft proteins which have a low internal stability such as bovine serum albumin (BSA). Therefore during the adsorption process on solid surfaces, these two kinds of proteins exhibit different behaviors (Haynes et al., 1994; Kleijn and Norde, 1995). On charged surfaces hard proteins can be adsorbed without modification of their structural conformation as opposed to soft proteins. The adsorption process implies complicated mechanisms in which solution conditions ( $\mathrm{pH}$ and ionic strength) and clay mineral surface properties (Quiquampoix et al., 1993; Haynes and Norde, 1994; Staunton and Quiquampoix, 1994) have been shown to be determining. Indeed, maximum of adsorption is achieved for solution $\mathrm{pH}$ close to the protein isoelectric point (IP) while it increases continuously with the ionic strength. For instance, proteins intercalation in layered materials such as clay minerals may occur even at $\mathrm{pH}$ above the protein IP where the protein and the mineral surface bear charges of the same sign. Moreover, it has been observed that, the nature of the cation in 
solution, as well as in the interlayer space of the material, (so called Interlayer Cation -IC-) influences the adsorption of proteins (Czajkowsky and Shao, 2003) on smectites. For instance, it has been emphasized that homoionic $\mathrm{Ca}^{2+}$ bentonites adsorb less proteins than their $\mathrm{Na}^{+}$ counterpart, due to their different swelling properties (Marchal et al., 1995). It is well known that IC of montmorillonite (Mt) have a major influence on its swelling property and, hence, on its capacity to interact with small polar molecules such as water (Kharroubi et al., 2009) and stabilize proteins. Thus other mechanisms than a simple ion exchange by one protein are involved in protein adsorption, with important practical consequences for applications. (Zhou, 2008) Usually IC can be separated into two groups (Collins, 1997): (i) the chaotrope cations (such as $\mathrm{K}^{+}, \mathrm{Rb}^{+}$and $\mathrm{Cs}^{+}$) destabilize proteins in solution and hinder the Mt swelling and (ii) the kosmotrope cations ( such as $\mathrm{Li}^{+}, \mathrm{Na}^{+}, \mathrm{Mg}^{2+}, \mathrm{Ca}^{2+}$ and $\mathrm{Ba}^{2+}$ ) have the opposite effect. In addition some ions increase the thermal stability of proteins in solution (Tadeo et al., 2007; Boncina et al., 2010). In this context, it is important to understand how IC drive the adsorption of proteins on smectite such as Mt.

The present work aims to follow the adsorption of two model proteins on a natural montmorillonite (SWy-2 from the Clay Mineral Society) exchanged with the series of alkali cation, $\left(\mathrm{Li}^{+}, \mathrm{Na}^{+}, \mathrm{K}^{+}, \mathrm{Rb}^{+}\right.$and $\left.\mathrm{Cs}^{+}\right)$, and three earth-alkali cation, $\left(\mathrm{Mg}^{2+}, \mathrm{Ca}^{2+}\right.$ and $\left.\mathrm{Ba}^{2+}\right)$. BSA and LYS were used as models for soft and hard proteins respectively. The influence of IC of Mt on their loading was investigated using several characterization techniques such as X-ray diffraction, transmission electron microscopy, UV absorbance and fluorescence emission spectra.

\section{Materials and methods}

2.1. Homoionic clay mineral preparation and characterization

The montmorillonite extracted from the Crook county (Wyoming) has been purchased at the Source Clays Repository (Clay mineral Society ref: Srce_Clay_SWy-2, for more details see 
http://www.clays.org/). This clay mineral has the chemical formula (Mermut and Cano,

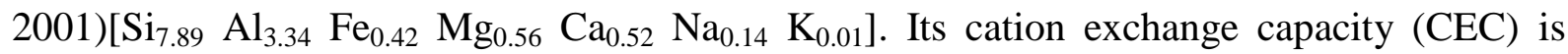
reported to be about 75meq/100g (Van Olphen and Fripiat, 1979). The present work is carried out on clay mineral fraction $\leq 2 \mu \mathrm{m}$ obtained by dispersion, sedimentation and centrifugation. The cation exchanges are performed in $1 \mathrm{M}$ solution of pure $\mathrm{LiCl}, \mathrm{NaCl}, \mathrm{KCl}, \mathrm{RbCl}, \mathrm{CsCl}$, $\mathrm{CaCl}_{2}, \mathrm{MgCl}_{2}$ or $\mathrm{BaCl}_{2}$ (Sigma, 99,9\%) in de-ionized water. Samples preparation and elementary analysis have been previously described (Haouzi et al., 2004; Kharroubi et al., 2012).

\subsection{UV absorbance and fluorescence emission spectra}

The UV absorbance spectra were recorded on JASCO V-570 UV-Vis spectrophotometer at 1 nm. $\mathrm{s}^{-1}$ scanning rate. All the solutions used for absorption measurement were filtered on low protein binding Durapore ${ }^{\circledR}$ membrane (Millex-HV 0.45 $\mu$ m PDMF) in order to limit the light scattering due to clay microparticles. Moreover to limit the error due to non specific protein adsorption, filters were previously flushed with a protein solution. They have then be filtered. Finally the filters were flushed with $250 \mu 1$ of sample. This experimental protocol has been previously tested with protein solution to evaluate the loss of protein concentration induced by filtration. The results have shown a good reproducibility and a less than $1 \%$ error. BSA and LYZ concentrations were obtained by absorbance measurement at $280 \mathrm{~nm}$, using $\varepsilon_{280} 44309$ $\mathrm{mol}^{-1} \mathrm{~cm}^{-1}$ and $36000 \mathrm{~mol}^{-1} \mathrm{~cm}^{-1}$ respectively. The fluorescence spectra were obtained on a SPEX spectrometer (Fluorolog 1681) at $1 \mathrm{~nm} \mathrm{~s}^{-1}$ scanning rate.

\subsection{Determination of protein adsorption on homoionic clay mineral}

BSA (A2153) and LYS from chicken egg white (62971) were purchased from Sigma. The protein adsorption experiments were performed in sodium phosphate buffer saline solution 
(PBS) $50 \mathrm{mM}, \mathrm{NaCl} 150 \mathrm{mM}$ at $\mathrm{pH}=4.5$ for BSA and 8.8 for LYS. First, $10 \mathrm{ml}$ of protein solution was prepared with concentrations ranging from 0.7 to $3 \mathrm{mg} \cdot \mathrm{mL}^{-1}$ for BSA and 0.3 to $3 \mathrm{mg} \cdot \mathrm{mL}^{-1}$ for LYS. The mixture was stirred at $22^{\circ} \mathrm{C} \pm 1^{\circ} \mathrm{C}$. The initial concentration of protein in solution was determined before addition of homoionic Mt (10mg corresponding to $\left.1 \mathrm{mg} \cdot \mathrm{mL}^{-1}\right)$. The concentration of protein adsorbed on the clay mineral was obtained from the classical method of supernatant depletion. Typically, it is calculated from the decrease of the protein concentration in solution as a function of time. The samples $(1 \mathrm{~mL})$ of the suspension were centrifuged 8 min under relative centrifugal force $2697 \mathrm{~g}$. The protein concentration contained in the supernatant was determined by UV absorption at $280 \mathrm{~nm}$. The concentration (mass per unit mass of $\mathrm{Mt}$ ) of adsorbed protein on clay mineral is determined by:

$$
\Gamma_{t}=\frac{V\left(C_{0}-C_{t}\right)}{m}
$$

$\mathrm{V}$ is the total volume of the protein solution, $\mathrm{C}_{0}$ is the initial concentration of protein, $\mathrm{C}_{\mathrm{t}}$ is the concentration of protein in supernatant at time $\mathrm{t}$, and $\mathrm{m}$ is the mass of the clay mineral. With $\mathrm{V}(\mathrm{mL}), \mathrm{C}_{0}$ and $\mathrm{C}_{\mathrm{t}}\left(\mathrm{mg} \cdot \mathrm{mL}^{-1}\right)$, the interfacial concentration $\Gamma_{\mathrm{t}}$ of protein is given in $\mathrm{mg}$ of protein per mg of clay mineral (mg. $\mathrm{mg}_{\mathrm{Mt}}{ }^{-1}$ ).

\subsection{Dynamic light scattering (DLS)}

The mean size of clay mineral particles in solution is determined by photon cross-correlation spectroscopy (PCCS) on a Nanophox (Sympatec, France) before protein adsorption at $25^{\circ} \mathrm{C}$. Raw data were treated by the non-negative least squares model with robust filter. This model does not imply any particle shape nor distribution.

\subsection{Transmission electron microscopy (TEM)}

Micrographs were recorded on an JEOL JEM-100 CXII apparatus operating at 200keV. To prepare the sample a few milligrams of clay mineral powder are mixed in a Beem capsule 
with Agar 100 embedding resin. After polymerization at $60^{\circ} \mathrm{C}$ overnight, the blocks were cut using a microtome equipped with a diamond knife. The ultra thin slices $\sim 50 \mathrm{~nm}$, were put on copper grids and examined.

\subsection{X-ray diffraction (XRD)}

X-ray diffractograms were recorded in a conventional $\theta-\theta$ Bragg-Brentano configuration (Nifiltered $\mathrm{CuK}_{\alpha 1,2}=1.5418 \AA$ ) by using a model D8 Advance Bruker-AXS Powder X-ray diffractometer coupled with a linear Vantec-1 detector. The diffraction patterns were performed between 1 and $62^{\circ}(2 \theta)$ with angular and time steps of $0.0328^{\circ}$ and 1 s respectively. A beam stop and a slit, of variable divergence, were used. Finally, the active area of the detector was limited as much as possible in order to reduce the background scattering at low angle.

\section{Results and discussion}

\subsection{Homoionic clay mineral characterization}

The elementary analyses of exchanged montmorillonite are reported in table 1 . The cation exchange is almost complete and that the samples can be considered as homoionic. The particle size distribution determined by PCCS is around $1.6 \mu \mathrm{m}$ (in buffer at $\mathrm{pH} 8.8$ ) and 2.5 $\mu \mathrm{m}$ (in buffer at $\mathrm{pH} 4.5$ ) for alkali metal exchanged Mt and around $2 \mu \mathrm{m}$ (in buffer at $\mathrm{pH} 8.8$ ) and $3 \mu \mathrm{m}$ (in buffer at $\mathrm{pH} 4.5$ ) for the alkali-earth exchanged Mt. Therefore, it can be concluded that the particle size is influenced by the $\mathrm{pH}$ as well as by the nature of IC. This outcome can be correlated to the aggregation state (Mohan and Fogler, 1997) and to the swelling of the clay mineral particles. It has already been reported that the number of plates per particles increases with the size and charge of IC (Schramm and Kwak, 1982). Furthermore, it is well known that the swelling of the interlayer space is IC dependent 
(Kharroubi et al., 2012), e.g. the number of adsorbed water molecules is much more important for divalent IC than for monovalent ones.

\subsection{Protein adsorption}

The protein adsorption on each homoionic Mt has been performed at $\mathrm{pH} 8.8$ for LYS and $\mathrm{pH}$ 4.5 for BSA. According to their IP, 11.35 (LYS) and 4.7 (BSA), the global charge of each protein is positive in these experimental conditions. Besides, the surface electrical charge of Mt can be considered negative (Delgado et al., 1986), and thus the anions $\left(\mathrm{PO}_{4}{ }^{2-}\right.$ and $\left.\mathrm{Cl}^{-}\right)$in buffer solution cannot be adsorbed on clay mineral surface. Typical examples of the adsorption kinetics $\left(\mathrm{C}_{0}=3 \mathrm{mg} \mathrm{mL}^{-1}\right)$ are reported in Figure 1. Similar behaviors are observed for all the other homoionic montmorillonites. In each case a rapid increase of adsorption is observed at the beginning, and steady state is reached after about $30 \mathrm{~min}$ for LYS and $90 \mathrm{~min}$ for BSA.

\subsection{Protein denaturation}

Fluorescence spectroscopy is a powerful method to obtain information on major structural modifications of proteins (Haynes and Norde, 1994) since the photophysical properties of the Tryptophan (Trp) residue is directly affected by its neighborhood (Chen and Barkley, 1998). When proteins containing Trp are going through structural or environmental modifications, changes in their photophysical properties can be observed as for example a shift of the fluorescence emission spectrum (Vivian and Callis, 2001; Bonhenry et al., 2011). In phosphate buffer at $\mathrm{pH}=4.5$, BSA exhibits a maximum emission wavelength of fluorescence at $351 \mathrm{~nm}$ for an excitation at $290 \mathrm{~nm}$. When BSA is adsorbed onto Mt, this maximum is shifted to shorter wavelengths (19 $\mathrm{nm}$ to $12 \mathrm{~nm}$ depending on IC), thus indicating a structural modification of BSA (Servagent-Noinville et al., 2000). The maximum fluorescence emission wavelength is $338 \pm 1 \mathrm{~nm}$ for $\mathrm{Na}^{+}, \mathrm{Rb}^{+}, \mathrm{Ba}^{2+}$ and $333 \pm 1 \mathrm{~nm}$ for $\mathrm{Li}^{+}, \mathrm{K}^{+}, \mathrm{Mg}^{2+}, \mathrm{Ca}^{2+}$ and $\mathrm{Cs}^{+}$ 
(Figure 2a) IC. On the contrary, the fluorescence emission spectra of LYS are not significantly shifted when it is adsorbed on Mt independently of IC (Figure 2a). This outcome indicates that the adsorption of LYS does not lead to large structural modification.

\subsection{Protein localization}

The X-ray diffraction patterns of $\mathrm{Na}^{+} \mathrm{Mt}$ and $\mathrm{Ca}^{2+} \mathrm{Mt}$ samples exhibit the same characteristics as those of dioctaedral smectic (Figure 3)which is still clearly identified by $(h k l)$ reflections at $19.7^{\circ}(211), 35.3^{\circ}(213)$ and $62^{\circ}(633)$ [12]. The angular position of the (633) reflection at $62^{\circ}(1.49 \AA)$ indicates the predominance of dioctahedral domains in the octahedral sheets of the homoionic Mt. In addition to the conventional (hkl) clay reflections, all samples show an intense sharp diffraction peak at $26.8^{\circ}$ attributed to quartz impurity. The position of the (001) reflections depends on both the IC and the hydration state. The basal spacing $\mathrm{d}_{001}$ corresponds to the thickness of the interlayer space plus that of the aluminosilicate layer (about $9.6 \AA$ for a 2:1 clay mineral (Brindley and Brown, 1980; Brigatti et al., 2012). Prior to protein adsorption, the (001) diffraction peak of the $\mathrm{Na}^{+} \mathrm{Mt}\left(\right.$ resp. $\left.C a^{2+} \mathrm{Mt}\right)$ is located around $2 \theta=9^{\circ}\left(\right.$ resp. $\left.7.1^{\circ}\right)$, corresponding to an interlayer spacing of $12 \AA$ (resp.13.6 $\AA$ ). These data correspond to the adsorption of a monolayer of water molecules in the interlayer space of these homoionic $\mathrm{Mt}$ samples.

After the protein adsorption, for LYS/ $\mathrm{Na}^{+} \mathrm{Mt}$, the interbasal spacing equals $54 \AA$. A shoulder observed at $2 \theta\left(3.2^{\circ}\right)$ corresponds to the (002) reflection suggesting a good ordering in the clay mineral layers. The XRD pattern of $\mathrm{LYS} / \mathrm{Ca}^{2+} \mathrm{Mt}$ is characteristic of an interstratified layered material with two values of inter-reticular distances observed at low angles corresponding to 49 and $30 \AA$. It means that two populations of layers with different interlayer spaces coexist. As LYS of molecular dimensions of 40 x $40 \times 60 \AA^{3}$ is classified as a hard protein and provides fluorescence spectra revealing no denaturation when it is absorbed, it 
can be assumed that LYS is intercalated in all the interlayers of $\mathrm{Na}^{+} \mathrm{Mt}$ while it occupies only certain domains of the interlayer space of $\mathrm{Ca}^{2+} \mathrm{Mt}$. In the case of $\mathrm{BSA} / \mathrm{Na}^{+} \mathrm{Mt}$, a broad diffraction peak can be observed at $2 \theta=3^{\circ}$, which may correspond to the second order of a (001) reflection peak expected at a lower $2 \theta$ value (not observed). The $\mathrm{BSA} / \mathrm{Ca}^{2+} \mathrm{Mt}$ composite material exhibits several reflection peaks at low $2 \theta$ values centered on 1.8 and $4.9^{\circ}$, corresponding to interlayer distances of 49 and $18 \AA$ respectively. The estimated size, i.e. $40 \mathrm{x}$ $40 \times 140 \AA^{3}$, for BSA is not fully consistent with the interlayer spaces determined from XRD. If BSA were adsorbed inside the Mt interlayer space without deformation, the interlayer distance should be $62 \AA$ for the $\mathrm{BSA} / \mathrm{Na}^{+} \mathrm{Mt}$ hybrid material. Hence, it can be assumed that BSA is embedded in the Mt in a distorted form such as a compressed or denatured state. The same situation is likely present in the case of the BSA/ $\mathrm{Ca}^{2+} \mathrm{Mt}$. The sharp diffraction peaks observed on the XRD patterns of both hybrid protein-clay materials correspond to the adsorption of proteins on the external surfaces of the clay minerals particles. The protein adsorption is performed at $\mathrm{pH}$ below their respective IP and therefore suitable for adsorption on the negatively charged Mt surface as well as for ionic exchange with IC. It is noteworthy that the interlayer expansion differs between $\mathrm{Ca}^{2+} \mathrm{Mt}$ and $\mathrm{Na}^{+} \mathrm{Mt}$. This observation can be related to the swelling behavior of the Mt dependent on IC features. It can be noticed that the adsorption of both proteins on $\mathrm{Na}^{+} \mathrm{Mt}$ induces the intercalation of organic moieties with a single population of layers whereas the $\mathrm{Ca}^{2+} \mathrm{Mt}$ leads to composites.

TEM micrographs (figure 4) of the natural $\mathrm{Na}^{+} \mathrm{Mt}$ show a (001) reflection peak corresponding to $12 \AA$ in agreement with the value obtained by XRD (figure 3 ). The $d_{001}$ value measured from BSA/ $\mathrm{Na}^{+} \mathrm{Mt}$ micrograph is about $28 \AA$ (Figure 4). Considering the BSA dimensions obtained from deformation-field-based morphology topographical analysis (Lin et al., 2007b), it can be assumed that BSA is intercalated in an interlayer space. In the case of $\mathrm{BSA} / \mathrm{Ca}^{2+} \mathrm{Mt}$, the two inter-reticular distances indicate that BSA can be intercalated without 
important deformation in certain domains and not intercalated at all in some others. It can be observed (figure 4) that intercalation does not occur anywhere in the structure, i.e. some interlayer spaces are intercalated whereas some others are not. This observation is in agreement with XRD experiments. In the case of LYS/ $\mathrm{Na}^{+} \mathrm{Mt}$ the $d_{001}$ value obtained from TEM equals $24 \AA$ and hence does not fit with the XRD results. This can probably be explained by a denaturation of the protein due to analysis conditions (vacuum).

\subsection{IC Influence on protein adsorption}

Equilibrium parameters of proteins adsorption on clay minerals are usually determined using two isotherm models, i.e. Freundlich and Langmuir (Ralla et al., 2010). The first one is an empirical equation assuming that the saturation state is not reached. On the contrary the Langmuir model assumes that i) at equilibrium, desorption and adsorption occur, i.e. adsorption is reversible and ii) surface sites are occupied uniformly on the entire surface. In the case of proteins, the Langmuir model is commonly used when equilibrium state is reached although adsorption may be partially irreversible. The Langmuir isotherm can be linearized as followed $\left(1 / \Gamma_{\mathrm{e}}\right)$ vs $\left(1 / \mathrm{C}_{\mathrm{e}}\right)$ :

$\frac{1}{\Gamma_{e}}=\frac{1}{\Gamma_{m}}+\frac{1}{K \Gamma_{m}} \frac{1}{C_{e}}(\mathrm{eq} 2)$

$\mathrm{C}_{\mathrm{e}}$ is the protein concentration in solution at equilibrium $\left(\mathrm{mg} \cdot \mathrm{mL}^{-1}\right), \Gamma_{\mathrm{e}}$ the interfacial concentration of protein $\left(\mathrm{mg} \cdot \mathrm{mg}^{-1}\right) . \mathrm{C}_{\mathrm{e}}$ and $\Gamma_{\mathrm{e}}$ are obtained from $\mathrm{C}_{\mathrm{t}}$ and $\Gamma_{\mathrm{t}}$ at $\mathrm{t}=180 \mathrm{~min}$ (eq 1.), $\Gamma_{\mathrm{m}}$ is the maximum of interfacial concentration maximum of the protein, $\mathrm{K}$ is the adsorption equilibrium constant due to protein affinity with homoionic Mt. The adsorption isotherms were carried out for each homoionic Mt with initial proteins concentration from 0.7 to 3 mg. $\mathrm{mL}^{-1}$ for BSA and from 0.3 to $3 \mathrm{mg} \cdot \mathrm{mL}^{-1}$ for LYS. Experimental data have been fitted by eq.2 (Figure 5). The values of $\Gamma_{\mathrm{m}}$ and $\mathrm{K}$ obtained from the linear fitting (Figure 6) are reported on table 2 . 
For each protein, the values obtained (Table 2) can be compared assuming that the specific areas of all homoionic Mt samples are the same. If protein adsorption on clay mineral surface is due to an exchange between IC and protein, the expected result should be an increase of both, protein surface concentration and affinity following the Hofmeister series. The variation of BSA and LYS concentration on clay $\left(\Gamma_{\mathrm{m}}\right)$ as a function of IC radius are depicted in figure 6. The quantity of LYS adsorbed as a function of the monovalent IC decreases following Hoffmeister series $\mathrm{Li}^{+}>\mathrm{Na}^{+}>\mathrm{K}^{+}>\mathrm{Rb}^{+}>\mathrm{Cs}^{+}$, unlike the quantity of BSA which follows the series $\mathrm{Na}^{+}>\mathrm{Cs}^{+}>\mathrm{K}^{+}>\mathrm{Li}^{+}>\mathrm{Rb}^{+}$. The results also exhibit a greater protein adsorption on $\mathrm{Ca}^{2+} \mathrm{Mt}$ than $\mathrm{Na}^{+} \mathrm{Mt}$. This result is opposite than the ones previously reported in literature. In this case no protein intercalation has been observed in $\mathrm{Ca}^{2+} \mathrm{Mt}$ (Rodriguez et al., 1977; Theng, 1979; Blade and Boulton, 1988) contrarily than the present studies. Thus the latter should be explained the observed discrepancy. In addition, the maximum loading of both proteins adsorbed on homoionic clay mineral is obtained for $\mathrm{Mg}^{2+} \mathrm{Mt}$ and when going down in the alkaline-earth column. This behavior can be explained by the difference of Mt particle size between monovalent and divalent IC. The surface available for protein adsorption is both, the external surface of the particles and the interlayer surface accessible by the proteins. The increase of the particle size observed for divalent IC, is due to the number of water molecule in their coordination shell, inside the interlayer space. However considering that proteins are intercalated inside interlayer space, it can be assumed that the accessible area is the same for all homoionic Mt. The higher amount of protein adsorbed on divalent cation exchanged Mt should be interpreted by a lower kinetic barrier due to the increase of the interlayer space.

The equilibrium constant $\mathrm{K}$, which can be considered as an estimate of the adsorption affinity (Table 2), also depends on IC for both proteins (Figure 7). The main outcome is that K values are comprised between 1 and $7 \mathrm{mg} \mathrm{mg}_{\mathrm{Mt}}{ }^{-1}$ for all $\mathrm{IC}$ except $\mathrm{Ba}^{2+}, \mathrm{Na}^{+}$and $\mathrm{Li}^{+}$for BSA and not following strictly Hofmeister series. Protein adsorption involves several processes depending 
on various and complex parameters such as IC/surface, IC/protein and protein/surface affinity, protein structure modification, and protein dehydration. In order to get insights into the role played by IC on BSA and LYS adsorption on Mt, it is necessary to classify our experimental data with respect to IC features. These could be the ionic radius $\mathrm{Rc}$, the ion potential energy which is proportional to $\mathrm{z} / \mathrm{Rc}$ where $\mathrm{z}$ is the electric charge, the ion polarization, the rank in the Hofmeister series or the Jones-Dole coefficient which differentiates chaotrope $\left(\mathrm{K}^{+}, \mathrm{Rb}^{+}\right.$, $\left.\mathrm{Cs}^{+}\right)$from kosmotrope $\left(\mathrm{Ba}^{2+}, \mathrm{Ca}^{2+}, \mathrm{Mg}^{2+}, \mathrm{Li}^{+} \mathrm{Na}^{+}\right)$cations (Collins and Washabaugh, 1985). For instance, it has been underlined that kosmotrope IC stabilize proteins and increase the swelling of Mt (Kharroubi et al., 2012) as opposed to chaotrope IC. In addition, Mt swelling increases with the hardness of cation following $Z / R_{c}$ ratio. Figure 6 shows the variation of $K$ (table 2) as a function of charge over cation radius (Collins, 2004).

Concerning BSA adsorption, the value of $\mathrm{K}$ observed for kosmotrope IC clearly shows a better affinity to Mt. However, it can be noted that $\mathrm{Ca}^{2+}$ which is also a kosmotrope cation does not stabilize the BSA adsorption. The strong cations $\left(\mathrm{Mg}^{2+}, \mathrm{Ba}^{2+}, \mathrm{Na}^{+}\right.$and $\left.\mathrm{Li}^{+}\right)$have stabilizing effect on BSA structure in solution. In addition $\mathrm{Rb}^{+}$seems to stabilize BSA adsorption. BSA exhibits a modification of its tridimensional structure when it is adsorbed on Mt. In this case, the denaturation of BSA during the adsorption process should not be favorable and thus the affinity should decrease. Nevertheless these same cations increase Mt swelling. Thus a probable reason may be an antagonist effect between ion effect on protein stabilization and the increase of Mt swelling. Concerning LYS, the influence of IC shows a behavior symmetrical to BSA. Kosmotrope cations, except for $\mathrm{Ca}^{2+}$ decrease the affinity between protein and Mt. It can be noted that the $\mathrm{Rb}^{+}$increases the LYS affinity for Mt. These results are probably due to non-structural modifications and its smaller hydrodynamic radius compare to BSA, leading to a lesser sensitivity to Mt swelling.

\section{Conclusion}


We investigated the influence of IC of montmorillonite $\mathrm{Wy}-2$ on protein adsorption. LYS and BSA were used as models of hard and soft protein respectively. In accordance with this behavior, IC induced BSA denaturation, whereas no change was visible for LYS. IC have a major influence on both proteins adsorption. The adsorption of protein is higher in the presence of divalent IC compared to monovalent cation. This effect can be attributed to the increase of particle size, linked to the number of water molecules in ion coordination shell, which should induce a lower kinetic barrier. Concerning the monovalent IC interfacial concentration for LYS it obeys the Hofmeister series but not for BSA. The results obtained about adsorption constant do not follow strictly the Hofmeister series. The symmetric influence of IC observed for BSA and LYS can be explained by their size and their denaturation properties when adsorbed on Mt. The results shows that the usual chaotrope / kosmotrope classification and can be used to describe the behavior of Mt/protein system excepting for $\mathrm{Rb}^{+}$and $\mathrm{Ca}^{2+} \mathrm{IC}$.

\section{References}

Alkan, M., O. Demirbas, M. Dogan and O. Arslan, 2006. Surface properties of bovine serum albumin adsorbed oxides: Adsorption, adsorption kinetics and electrokinetic properties. Microporous and Mesoporous Materials 96(1-3), 331-340.

Blade, W. H. and R. Boulton, 1988. Adsorption of Protein by Bentonite in a Model Wine Solution. American Journal of Enology and Viticulture 39(3), 193-199.

Boncina, M., J. Lah, J. Rescic and V. Vlachy, 2010. Thermodynamics of the Lysozyme-Salt Interaction from Calorimetric Titrations. Journal of Physical Chemistry B 114(12), 4313-4319.

Bonhenry, D., S. Kraszewski, F. Picaud, C. Ramseyer, S. b. Balme, J. M. Janot and F. Henn, 2011. Stability of the gramicidin-A channel structure in view of nanofiltration: a computational and experimental study. Soft Matter 7, 10659.

Brigatti, M. F., E. Galan and B. K. G. Theng (2012). Structure and mineralogy of clay sciences. Handbook of Clay Science, Elsevier.

Brindley, G. W. and G. Brown, 1980. Crystal structures of clay minerals and their X-ray identification. London, Mineralogical Society.

Castellini, E., A. Ranieri, D. A. Simari and G. Di Rocco, 2009. Thermodynamic Aspects of the Adsorption of Cytochrome $c$ and its Mutants on Kaolinite. Langmuir 25(12), 6849-6855.

Chen, Y. and M. D. Barkley, 1998. Biochemistry 37(28), 9976.

Collins, K. D., 1997. Charge density-dependent strength of hydration and biological structure. Biophysical Journal 72(1), 65-76. 
Collins, K. D., 2004. Ions from the Hofmeister series and osmolytes: effects on proteins in solution and in the crystallization process. Methods 34(3), 300-311.

Collins, K. D. and M. W. Washabaugh, 1985. The Hofmeister Effect and the Behavior of Water at Interfaces. Quarterly Reviews of Biophysics 18(4), 323-422.

Czajkowsky, D. M. and Z. Shao, 2003. Inhibition of protein adsorption to muscovite mica by monovalent cations. Journal of Microscopy-Oxford 211, 1-7.

Delgado, A., F. González-Caballero and J. M. Bruque, 1986. On the zeta potential and surface charge density of montmorillonite in aqueous electrolyte solutions. Journal of Colloid and Interface Science 113(1), 203-211.

Ge, J., D. N. Lu, Z. X. Liu and Z. Liu, 2009. Recent advances in nanostructured biocatalysts. Biochem. Eng. J. 44, 53-59.

Haouzi, A., M. Kharroubi, H. Belarbi, S. Devautour-Vinot, F. Henn and J. C. Giuntini, 2004. Activation energy for dc conductivity in dehydrated alkali metal-exchanged montmorillonites: experimental results and model. Applied Clay Science 27(1-2), 67-74.

Haynes, C. A. and W. Norde, 1994. Globular proteins at solid/liquid interfaces. Colloids and Surfaces B: Biointerfaces 2(6), 517-566.

Haynes, C. A., E. Sliwinsky and W. Norde, 1994. Structural and Electrostatic Properties of GlobularProteins at a Polystyrene Water Interface. Journal of Colloid and Interface Science 164(2), 394-409.

Kharroubi, M., S. Balme, A. Haouzi, H. Belarbi, D. Sekou and F. Henn, 2012. Interlayer Cation-Water Thermodynamics and Dynamics in Homoionic Alkali and Alkaline-Earth Exchanged Montmorillonites with Low Water Loadings. Journal of Physical Chemistry C 116(28), 1497014978.

Kharroubi, M., S. Balme, F. Henn, J. C. Giuntini, H. Belarbi and A. Haouzi, 2009. Dehydration enthalpy of alkali-cations-exchanged montmorillonite from thermogravimetric analysis. Journal of Colloid and Interface Science 329(2), 339-345.

Kleijn, M. and W. Norde, 1995. The adsorption of proteins from aqueous solution on solid surfaces. Heterogeneous Chemistry Reviews 2(3), 157-172.

Lin, J.-J., J.-C. Wei, T.-Y. Juang and W.-C. Tsai, 2007a. Preparation of Protein-Silicate Hybrids from Polyamine Intercalation of Layered Montmorillonite. Langmuir 23, 1995-1999.

Lin, J. J., J. C. Wei, T. Y. Juang and W. C. Tsai, 2007b. Preparation of protein-silicate hybrids from polyamine intercalation of layered montmorillonite. Langmuir 23(4), 1995-1999.

Lvov Yu, M. and G. B. Sukhorukov, 1997. Protein architecture: assembly of ordered films by means of alternated adsorption of oppositely charged macromolecules. Membrane \& cell biology 11(3), 277-303.

Marchal, R., J. Barret and A. Maujean, 1995. Relations entre les caractéristiques physico-chimiques d'une bentonite et son pouvoir d'adsorption. J. Int. Sci. Vigne Vin. 29(1), 27-42.

Mermut, A. R. and A. F. Cano, 2001. Baseline studies of The Clay Minerals Society Source Clays: Chemical analyses of major elements. Clays and Clay Minerals 49(5), 381-386.

Mohan, K. K. and H. S. Fogler, 1997. Effect of pH and layer charge on formation damage in porous media containing swelling clays. Langmuir 13(10), 2863-2872.

Quiquampoix, H. (2000). Mechanisms of protein adsorption on surfaces and consequences for extracellular enzyme activity in soil. . Soil Biochemistry. J. M. Bollag and M. Stotzki. New York, Marcel Dekker.

Quiquampoix, H., S. Staunton, M. H. Baron and R. G. Ratcliffe, 1993. Interpretation of the PhDependence of Protein Adsorption on Clay Mineral Surfaces and Its Relevance to the Understanding of Extracellular Enzyme-Activity in Soil. Colloids and Surfaces aPhysicochemical and Engineering Aspects 75, 85-93.

Ralla, K., U. Sohling, D. Riechers, C. Kasper, F. Ruf and T. Scheper, 2010. Adsorption and separation of proteins by a smectitic clay mineral. Bioprocess and Biosystems Engineering 33(7), 847-861.

Rodriguez, P., A. Weiss and G. Lagaly, 1977. A natural caly organic complex from Andalusian black earth. Clays and Clay Minerals 25, 243-251. 
Schramm, L. L. and J. C. T. Kwak, 1982. Influence of Exchangeable Cation Composition on the Size and Shape of Montmorillonite Particles in Dilute Suspension. Clays and Clay Minerals 30(1), 4048.

Servagent-Noinville, S., M. Revault, H. Quiquampoix and M. H. Baron, 2000. Conformational changes of bovine serum albumin induced by adsorption on different clay surfaces: FTIR analysis. Journal of Colloid and Interface Science 221(2), 273-283.

Staunton, S. and H. Quiquampoix, 1994. Adsorption and Conformation of Bovine Serum-Albumin on Montmorillonite - Modification of the Balance between Hydrophobic and Electrostatic Interactions by Protein Methylation and Ph Variation. Journal of Colloid and Interface Science 166(1), 89-94.

Tadeo, X., M. Pons and O. Millet, 2007. Influence of the hofmeister anions on protein stability as studied by thermal denaturation and chemical shift perturbation. Biochemistry 46(3), 917923.

Theng, B. K. G. (1979). Formation and Properties of Clay-Polymer Complexes, Elsevier.

Van Olphen, H. and J. J. Fripiat (1979). Data Handbook for Clay Minerals andother Non-Metallic Minerals,. London, Pergamon Press.

Vivian, J. T. and P. R. Callis, 2001. Biophysical Journal. 80(5), 2093.

Zhou, H.-X., 2008. Protein folding in confined and crowded environments. Arch. Biochem. Biophys. 469(1), 76-82. 


\section{Figure legend}

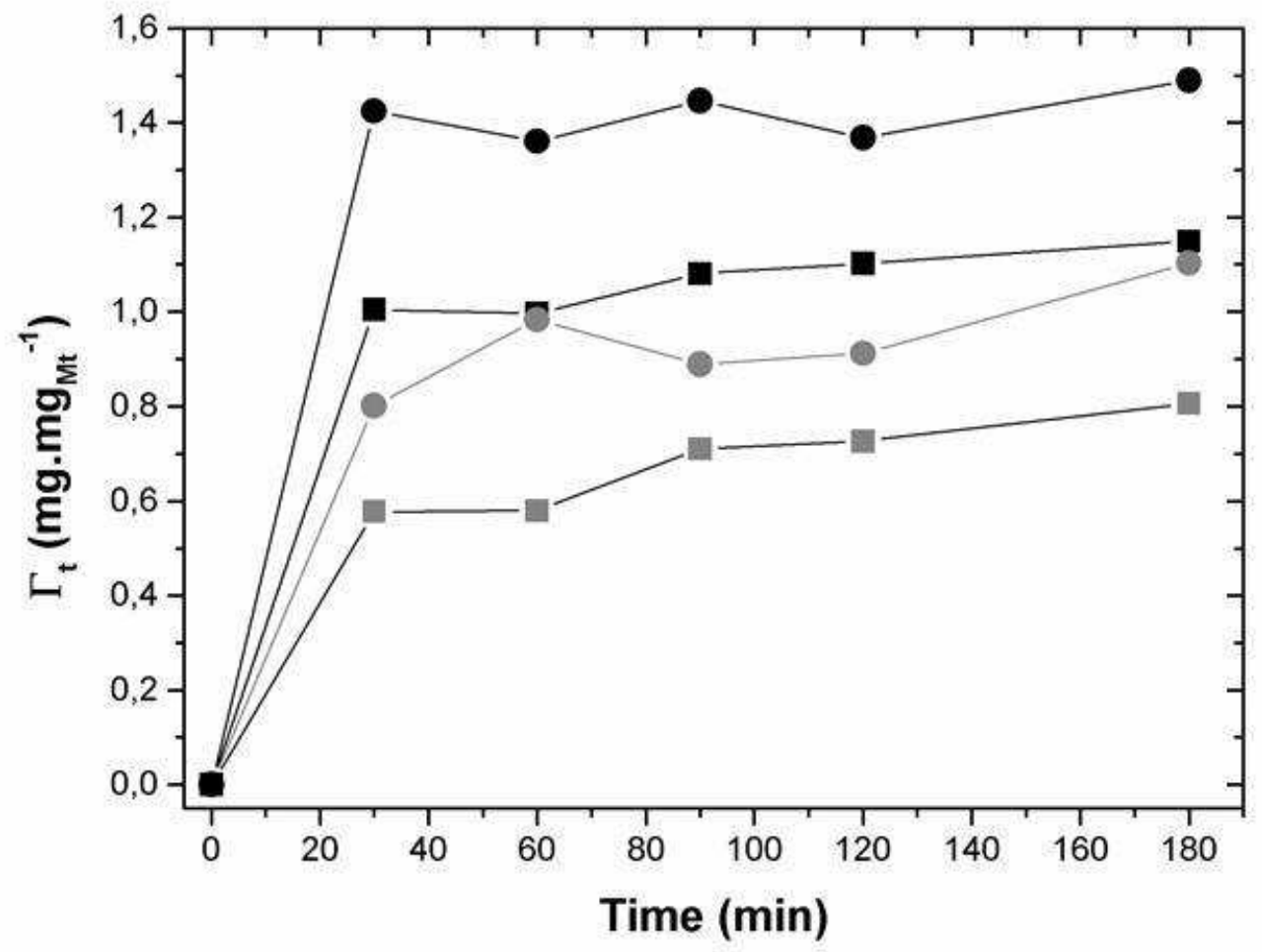

Figure 1 : Adsorption kinetics of BSA at pH 4.5 (gray) and LYS at pH 8.8 (black) absorbed on $\mathrm{Na}^{+} \mathrm{Mt}$ (square) and $\mathrm{Ca}^{2+} \mathrm{Mt}$ (round)
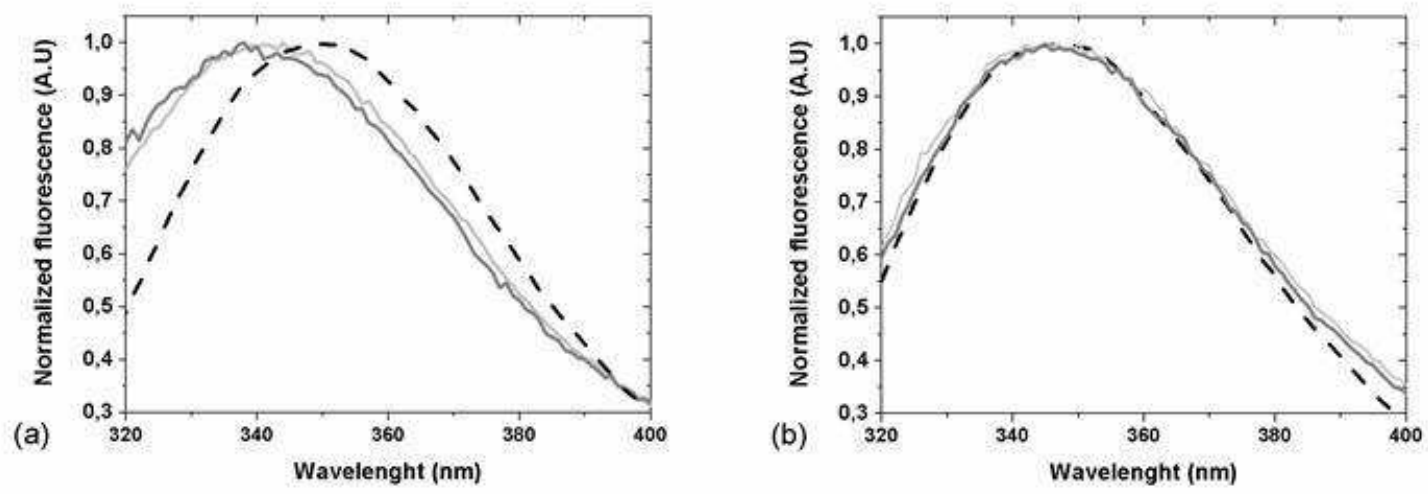

Figure 2 : Examples of fluorescence emission spectra (excitation wavelength $290 \mathrm{~nm}$ ) of (a) BSA in buffer solution $\mathrm{pH} 4.4$ (black, dash line), adsorbed on $\mathrm{Ba}^{2+} \mathrm{Mt}$ ( light gray) and 
$\mathrm{Ca}^{2+} \mathrm{Mt}$ (gray) (b) LYS in buffer solution $\mathrm{pH} 8.8$ (black, dash line), adsorbed on $\mathrm{Ba}^{2+} \mathrm{Mt}($ light gray) and $\mathrm{Ca}^{2+} \mathrm{Mt}$ (gray)
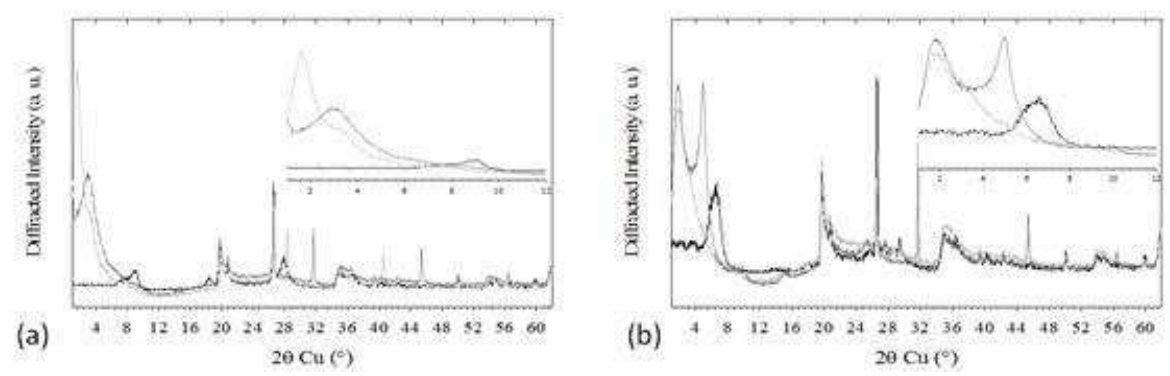

Figure 3: a) X-ray diffraction patterns of the $\mathrm{Na}^{+} \mathrm{Mt}$ before (black) and after the adsorption of BSA (dark gray) and LYS (gray) proteins. b) X-Ray Diffraction patterns of the initial Mt-Ca ${ }^{2+}$ (black) and the resulting intercalated hybrid materials after adsorption of BSA (dark gray) and LYS (gray) proteins.
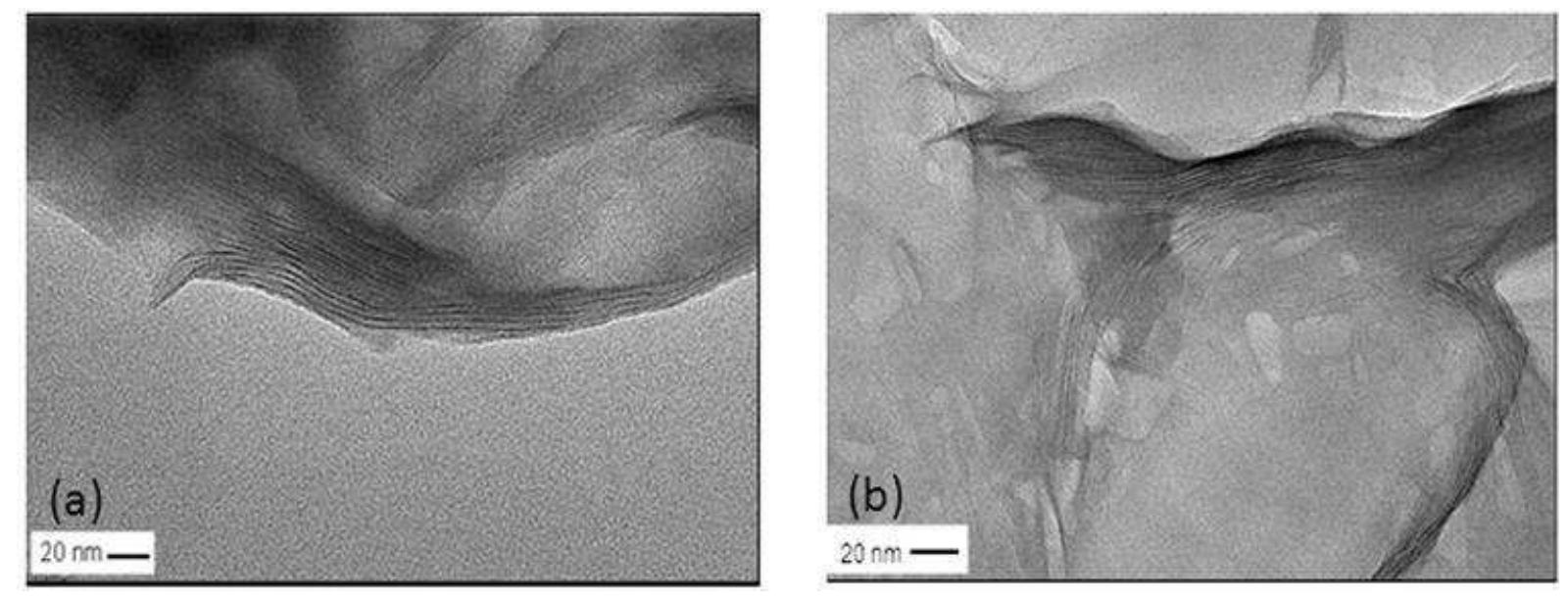

Figure 4 : TEM micrographs of (a) LYS adsorbed on $\mathrm{Na}^{+} \mathrm{Mt}$ and (b) BSA adsorbed $\mathrm{Na}^{+} \mathrm{Mt}$

(a)

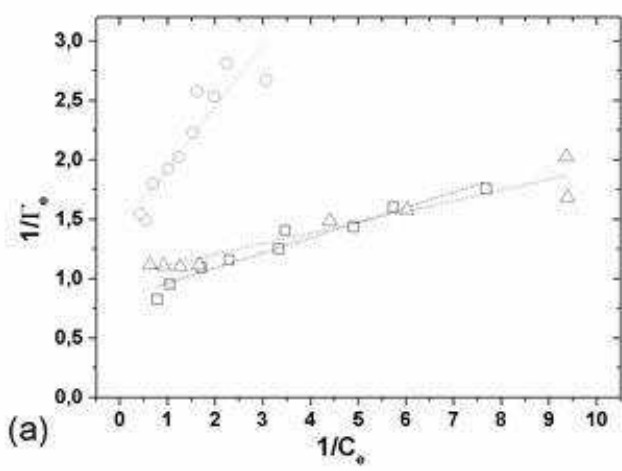

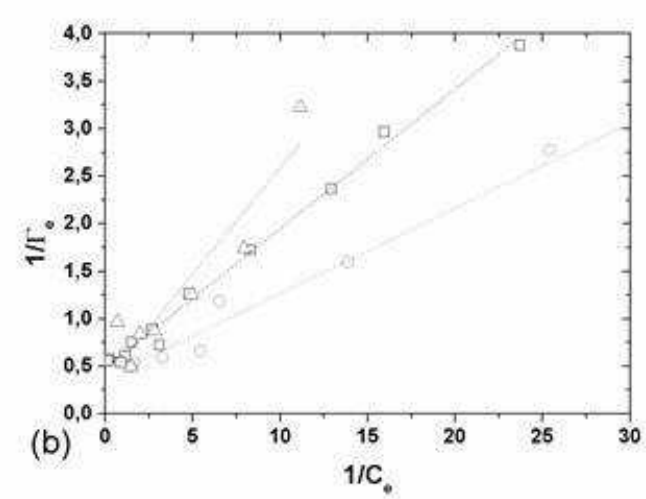


Figure 5 : Examples of Langmuir isotherm of (a) BSA on homoionic $\mathrm{Mt}: \mathrm{Na}^{+}$(dark gray triangle), $\mathrm{K}^{+}$(gray circle) and $\mathrm{Mg}^{2+}$ (black square) (b) LYS on homoionic $\mathrm{Mt}: \mathrm{Na}^{+}$(black square), $\mathrm{Ba}^{2+}$ (dark gray triangle) and $\mathrm{Ca}^{2+}$ (gray circle)

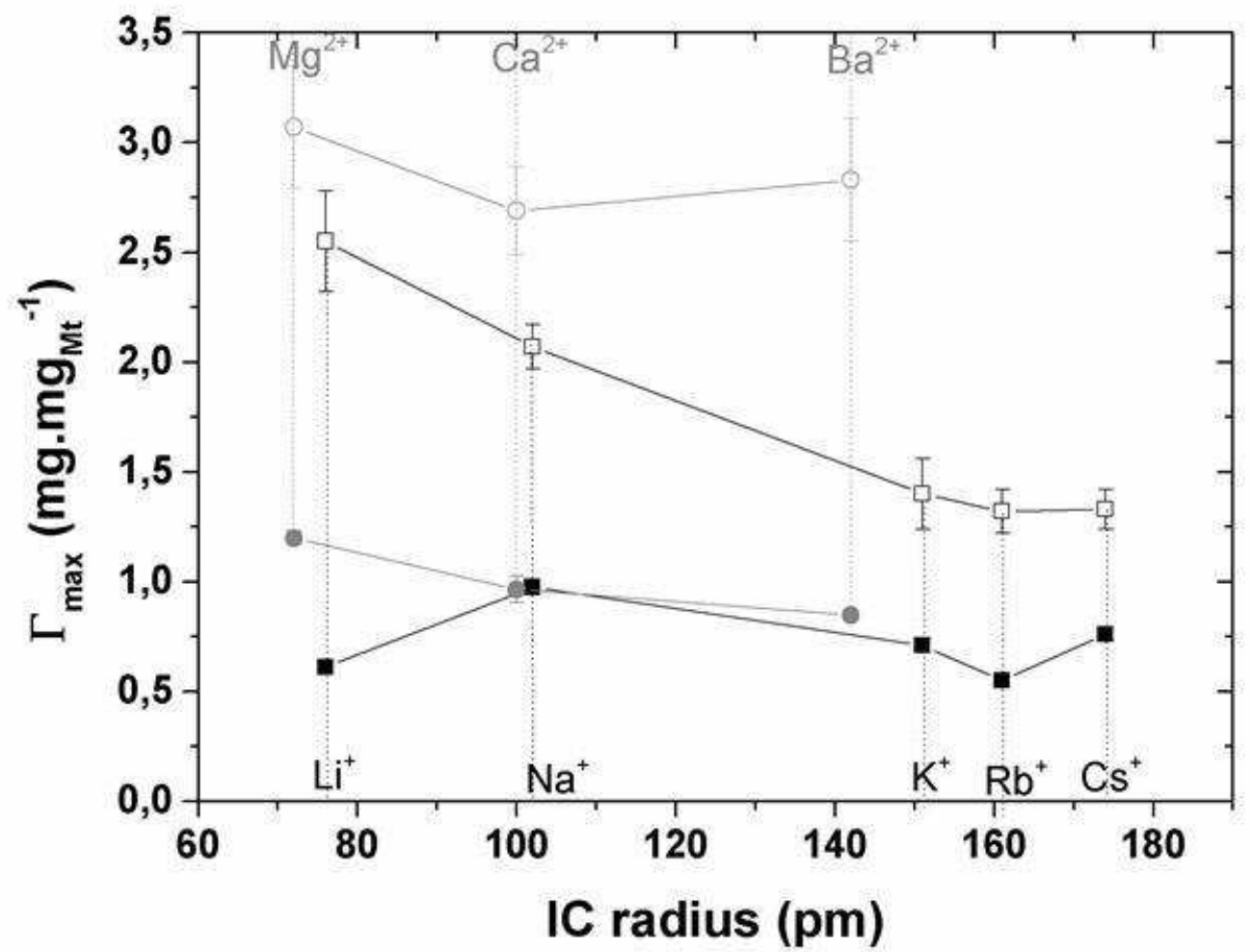

Figure 6 : Maximum surface concentration obtained from eq (2) of BSA (full symbol) and LYS (open symbol) adsorbed of homoionic Mt as function IC radius
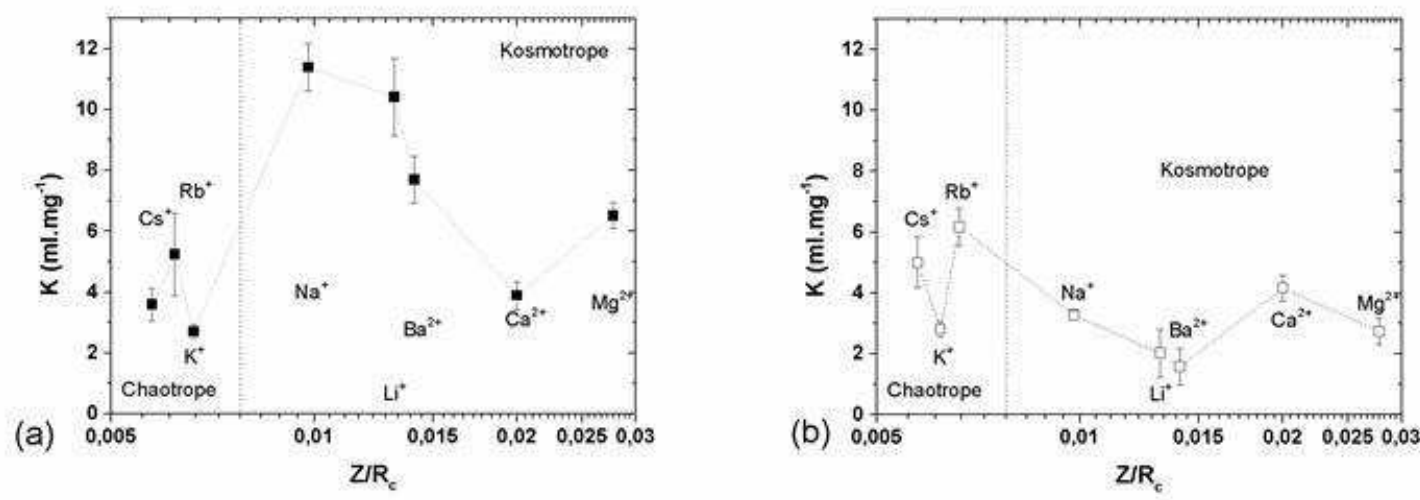
Figure 7 : Equilibrium constant K obtained from eq (2) of BSA (a) and LYS (b) adsorbed of homoionic Mt as function $\mathrm{Z} / \mathrm{R}_{\mathrm{c}}$ 
Table legend

\begin{tabular}{|l|l|}
\hline Mt-Li & $\left(\mathrm{Si}_{3.96}\right)^{\mathrm{IV}}\left(\mathrm{Al}_{1.46}, \mathrm{Fe}^{3+}{ }_{0.18}, \mathrm{Mg}_{0.21}\right)^{\mathrm{VI}} \mathrm{Na}_{0.02} \mathrm{Ca}_{0.03} \mathbf{L i}_{\mathbf{0 . 2 5}} \mathrm{K}_{0.019} \mathrm{O}_{10}(\mathrm{OH})_{2}$ \\
\hline Mt-Na & $\left(\mathrm{Si}_{3.94}\right)^{\mathrm{I}}\left(\mathrm{Al}_{1.49}, \mathrm{Fe}^{3+}{ }_{0.18}, \mathrm{Mg}_{0.21}\right)^{\mathrm{VI}} \mathrm{Na}_{0.3} \mathrm{Ca}_{0.01} \mathrm{~K}_{0.02} \mathrm{O}_{10}(\mathrm{OH})_{2}$ \\
\hline Mt-K & $\left(\mathrm{Si}_{3.92}\right)^{\mathrm{IV}}\left(\mathrm{Al}_{1.52}, \mathrm{Fe}^{3+}{ }_{0.2}, \mathrm{Mg}_{0.22}\right)^{\mathrm{VI}} \mathrm{Na}_{0.03} \mathrm{Ca}_{0.02} \mathbf{K}_{\mathbf{0 . 3 1}} \mathrm{O}_{10}(\mathrm{OH})_{2}$ \\
\hline Mt-Rb & $\left(\mathrm{Si}_{3.44}\right)^{\mathrm{IV}}\left(\mathrm{Al}_{1.55}, \mathrm{Fe}^{3+}{ }_{0.19}, \mathrm{Mg}_{0.23}\right)^{\mathrm{VI}} \mathrm{Ca}_{0.03} \mathbf{R b}_{\mathbf{0 . 2 8}} \mathrm{K}_{0.03} \mathrm{O}_{10}(\mathrm{OH})_{2}$ \\
\hline Mt-Mg & $\left(\mathrm{Si}_{3.04}\right)^{\mathrm{IV}}\left(\mathrm{Al}_{1.5}, \mathrm{Fe}^{3+}{ }_{0.18}, \mathrm{Mg}_{0.22}\right)^{\mathrm{VI}} \mathrm{Ca}_{0.03} \mathbf{C s}_{\mathbf{0 . 3 3}} \mathrm{O}_{10}(\mathrm{OH})_{2}$ \\
\hline Mt-Ca & $\left(\mathrm{Si}_{3.84}\right)^{\mathrm{IV}}\left(\mathrm{Al}_{1.57}, \mathrm{Fe}^{3+}{ }_{0.19}, \mathrm{Mg}_{0.2}\right)^{\mathrm{VI}} \mathbf{M g}_{0.18} \mathrm{O}_{10}(\mathrm{OH})_{2}$ \\
\hline Mt-Ba & $\left(\mathrm{Si}_{3.87}\right)^{\mathrm{IV}}\left(\mathrm{Al}_{1.6}, \mathrm{Fe}^{3+}{ }_{0.19}, \mathrm{Mg}_{0.2}\right)^{\mathrm{VI}} \mathbf{C a}_{0.18} \mathrm{O}_{10}(\mathrm{OH})_{2}$ \\
& $\left(\mathrm{Si}_{3.8}\right)^{\mathrm{IV}}\left(\mathrm{Al}_{1.56}, \mathrm{Fe}^{3+}{ }_{0.19}, \mathrm{Mg}_{0.2}\right)^{\mathrm{VI}} \mathbf{B a}_{\mathbf{0 . 1 7}} \mathrm{O}_{10}(\mathrm{OH})_{2}$ \\
\hline
\end{tabular}

Table 1 : Chemical formula of homoinic exchanged Mt(Kharroubi et al., 2012)

\begin{tabular}{|c|c|c|c|c|}
\hline & \multicolumn{2}{|c|}{ LYS } & \multicolumn{2}{|c|}{ BSA } \\
\hline IC & $\Gamma_{\mathrm{m}}\left(\mathrm{mg} \mathrm{mg}_{\mathrm{Mt}}{ }^{-1}\right)$ & $\mathrm{K}\left(\mathrm{ml} \mathrm{mg}{ }^{-1}\right)$ & $\Gamma_{\mathrm{m}}\left(\mathrm{mg} \mathrm{mg}_{\mathrm{Mt}}^{-1}\right)$ & $\mathrm{K}\left(\mathrm{ml} \mathrm{mg}{ }^{-1}\right)$ \\
\hline $\mathrm{Li}^{+}$ & $2.55 \pm 0.23$ & $2.00 \pm 0.79$ & $0.61 \pm 0.02$ & $10.41 \pm 1.27$ \\
\hline $\mathrm{Na}^{+}$ & $2.07 \pm 0.10$ & $3.27 \pm 0.15$ & $0.98 \pm 0.02$ & $11.39 \pm 0.77$ \\
\hline $\mathrm{K}^{+}$ & $1.40 \quad \pm 0.16$ & $6.17 \pm 0.62$ & $0.71 \pm 0.03$ & $2.71 \pm 0.22$ \\
\hline $\mathrm{Rb}^{+}$ & $1.32 \pm 0.10$ & $2.82 \pm 0.26$ & $0.55 \pm 0.02$ & $5.24 \pm 1.36$ \\
\hline $\mathrm{Cs}^{+}$ & $1.33 \pm 0.09$ & $5.00 \pm 0.83$ & $0.76 \pm 0.03$ & $3.59 \pm 0.54$ \\
\hline $\mathrm{Mg}^{2+}$ & $3.07 \pm 0.28$ & $2.74 \pm 0.44$ & $1.20 \pm 0.03$ & $6.52 \pm 0.43$ \\
\hline $\mathrm{Ca}^{2+}$ & $2.69 \pm 0.20$ & $4.16 \pm 0.42$ & $0.97 \pm 0.06$ & $3.89 \pm 0.46$ \\
\hline $\mathrm{Ba}^{2+}$ & $2.84 \pm 0.28$ & $1.58 \pm 0.60$ & $0.85 \pm 0.02$ & $7.7 \pm 0.76$ \\
\hline
\end{tabular}

Table 2 : Adsorption parameter obtained by Langmuir isotherm for BSA and LYS adsorption on homoionic Mt 